\title{
Oferta programowa, katalogi \\ i imperializm kulturowy *
}

\author{
RAMON LOBATO
}

Niech rozpocznie się rzeź! ${ }^{1}$

Umiędzynarodowienie Netfliksa nasunęło sporo interesujących pytań o ofertę programową, $\mathrm{z}$ których wiele wiąże się z debatą obecną od dawna w badaniach nad mediami i komunikacją na temat źródła i natężenia międzynarodowych przepływów na rynku programów telewizyjnych. Kwestią, która budzi największe kontrowersje, jest znikomy udział lokalnych treści w ofercie Netfliksa, zdominowanej przez produkcje ze Stanów Zjednoczonych. Ted Sarandos, dyrektor firmy ds. programowych, wielokrotnie zwracał uwagę, że tworząc katalogi na zagraniczne rynki, sięga po „tajemną recepturę", która przewiduje około $15-20$ proc. lokalnych treści i 80-85 proc. produkcji z Hollywood lub innych międzynarodowych programów ${ }^{2}$. Netflix definiuje lokalność dość luźno - w przypadku rynków anglojęzycznych może ona oznaczać mieszankę treści brytyjskich i amerykańskich, podczas gdy w państwach Ameryki Południowej do lokalnych mogą się zaliczać filmy produkcji hiszpańskiej czy meksykańskiej, a w świecie arabskim - egipskie i tureckie opery mydlane. W istocie stosunkowo niewielka część zagranicznych katalogów Netfliksa - co w szczególności odnosi się do niedużych rynków lub takich, które cechuje język o małym zasięgu kulturowym - oferuje 20 proc. treści rodzimych dla danego kraju. Mniejsze rynki często muszą się zadowalać towarem z przeceny, przypadkową mieszanką programów, które Netflix dystrybuuje na podstawie licencji wykupionej okazyjnie na warunkach obowiązujących globalnie. W każdym razie we wszystkich katalogach krajowych - po uwzględnieniu zarówno licencjonowanych tytułów, jak i oryginalnych produkcji Netflixa - wyraźną przewagę mają programy amerykańskie.

Netflix nie zamierza się kajać. Na stronie z informacjami dla inwestorów wyjaśnia: na naszych rynkach treści lokalne stanowia mniejszość. Firma traktuje swoje strategiczne i mniej ważne, pojedyncze inwestycje w oryginalne rodzime treści jako sposób na wprowadzenie subskrybentów w zasady działania serwisu i zaznajomienie ich z naszym globalnym (czyli amerykańskim) katalogiem. Jak zaznacza: jej celem nie jest powielanie oferty programowej miejscowego nadawcy czy sieci telewizyjnej obecnej na danym rynku, lecz uzupetnianie ustugi lokalnymi treściami w stosownych przypadkach ${ }^{3}$.

* Tekst jest tłumaczeniem rozdziału Content, Catalogs, and Cultural Imperialism z książki Ramona Lobato Netflix Nations. The Geography of Digital Distribution, New York University Press, New York 2019 (http://opensquare.nyupress.org/books/9781479804948/read/) (C) 2019 by New York University. 


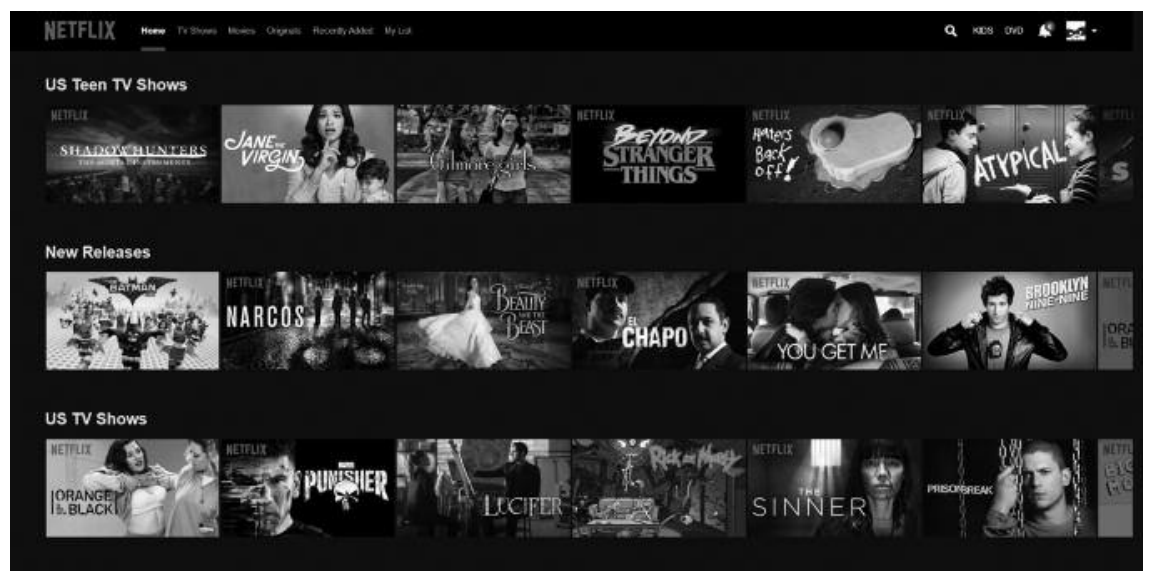

Ilustracja 1. Netflix - globalna tuba dla treści z USA? (Zrzut ekranu wykonany przez autora).

Dla państw o silnych tradycjach w zakresie regulacji rodzimych treści może to stanowić problem. W przypadku niektórych rynków Netflix konkuruje dziś z nadawcami i operatorami płatnej telewizji, których warunki licencji zobowiązują do emisji znacznej ilości lokalnych, krajowych lub regionalnych treści. Jako serwis typu OTT ${ }^{4}$ Netflix zasadniczo nie podlega tym wymogom. Dlatego instytucje regulacyjne, a także organizacje branżowe i obywatelskie przyglądają się coraz uważniej katalogom Netfliksa w swoich krajach, a nawet zlecają analizę oferowanych treści.

W Kanadzie, gdzie Netflix jest obecny od 2010 r., badania przeprowadzone na zlecenie Canadian Radio-Television and Telecommunications Commission wykazały, że jego tamtejszy katalog obejmuje jedynie około 3,3 proc. kanadyjskich filmów pełnometrażowych i 13,7 proc. programów telewizyjnych ${ }^{5}$. Gdy w 2015 r. Netflix wchodził na rynek australijski, miał w lokalnym katalogu tylko 34 australijskie filmy i podobną liczbę programów telewizyjnych ${ }^{6}$. Badania przeprowadzone niedawno przez Europejskie Obserwatorium Audiowizualne dowiodły, że w 28 europejskich katalogach Netfliksa produkcje hollywoodzkie stanowią średnio ponad dwie trzecie oferowanych tytułów filmowych ${ }^{7}$. W katalogach dostępnych w większości państw Europy - na przykład w Austrii, Bułgarii, Chorwacji, na Cyprze, w Czechach, Estonii, Finlandii, Grecji, na Litwie, Łotwie i Malcie, w Rumunii i Słowenii, na Słowacji i na Węgrzech - nie znalazł się ani jeden film rodzimej produkcji ${ }^{8}$.

Jak wynika z tych danych, rozwój Netfliksa stanowi wyzwanie dla obecnej polityki medialnej, szczególnie tej dotyczącej lokalnych treści, stworzonej w epoce nadawania (broadcast), której celem jest utrzymanie pewnej dynamicznej, ale trwałej równowagi między rodzimymi treściami medialnymi, a tymi, które pocho$d z a$ zza oceanu ${ }^{9}$. Decydenci próbujący nadążyć za zawrotnym tempem zmian technologicznych coraz częściej zwracają uwagę na ten serwis i dopytują: Czy „hollywoodocentryzm” Netfliksa jest problemem? Jak serwis wypada pod tym względem na tle lokalnych kanałów nadawczych i płatnej telewizji? Czy od Netfliksa należy oczekiwać, że będzie prezentował i wspierał lokalne produkcje? Czy dostarcza różnorodnych perspektyw na świat, czy też stanowi kolejny nośnik dominacji amerykańskiej? 
Pytania te wymagają uważnego namysłu, jako że często łączą się z normatywnymi założeniami na temat relacji między mediami narodowymi i globalnymi. W tym kontekście należy się również zastanowić, jak mocna jest pozycja Netfliksa na poszczególnych rynkach krajowych i jakie oczekiwania (nie zawsze tożsame) mają tamtejsi widzowie i prawodawcy. Traktując katalog Netfliksa jako przedmiot polityki medialnej, jak i polityki w ogóle, przyjrzę się niektórym sporom wokół oferty programowej serwisu, które pojawiły się w różnych krajach, a także prześledzę, jak w tym kontekście rozwijały się w ostatnich latach debaty na temat regulacji mediów.

\section{Jednokierunkowy przepływ treści?}

Dzisiejsza dyskusja o katalogach Netfliksa przypomina wcześniejszą, znaną pewnie wielu czytelnikom debatę odbywającą się na gruncie międzynarodowych badań nad telewizją. Od lat 70. XX w. medioznawcy, twórcy polityki medialnej i aktywiści prowadzą bowiem ożywiony spór o imperializm kulturowy, czyli masowy eksport mediów, informacji i kultury z Zachodu do „reszty świata”, prowadzący do zależności gospodarczej i kulturowej. Koncepcja imperializmu kulturowego pojawiła się w debacie publicznej na przełomie lat 60. i 70. dzięki pracom Herberta Schillera, Armanda Mattelarta, Allana Wellsa i Jeremy'ego Tunstalla ${ }^{10}$. Zyskała też wymiar instytucjonalny za sprawą badań i debat na forum UNESCO, gdy w latach 70. niedawno wyzwolone z kolonializmu narody Afryki i Azji proklamowały kulturową niezależność od byłych potęg imperialnych.

Spory o imperializm kulturowy pozostawiły w medioznawczych badaniach nad telewizją dziedzictwo w postaci często krytykowanej koncepcji jednokierunkowego przepływu, która opiera się na tezie, że Stany Zjednoczone (i - w mniejszym stopniu - Zjednoczone Królestwo oraz Europa Zachodnia) zdominowały światowy rynek telewizyjny dzięki masowemu eksportowi filmów i seriali, niejednokrotnie celowo zalewając go treściami sprzedawanymi po cenach dumpingowych. Wedle tej teorii amerykański eksport jest tanim sposobem na wypełnienie lokalnych ramówek, tworzącym stosunek zależności między centrum i peryferiami. W efekcie seriale CSI: Kryminalne zagadki Las Vegas (CSI, 2000-2015) i Chirurdzy (Grey's Anatomy, 2005-) można obejrzeć niemal wszędzie, podczas gdy flagowe produkcje z innych części świata rzadko przekraczają granice swoich ojczyzn.

Teoria jednokierunkowego przepływu podzieliła badaczy, jednak choć wysuwano przeciw niej argumenty zarówno konceptualne, jak i empiryczne, pozostaje wpływowym memem w światowych dyskusjach na temat polityki medialnej. W tym kontekście trzeba pamiętać, że istnieje różnica między teoriami wyjaśniającymi a realnymi dyskursami, które kształtują politykę i praktykę. Kluczowe znaczenie ma nie tyle zasadność lub bezzasadność koncepcji jednokierunkowego przepływu, ile utrzymujące się wciąż u wielu osób p o c z u c i e, że przepływ treści istotnie odbywa się w jednym kierunku - dlatego warto wiedzieć, skąd się wzięła ta idea i jak oddziałuje na współczesne dyskusje na temat usług telewizyjnych świadczonych za pośrednictwem Internetu.

Kluczowym dokumentem jest tu raport UNESCO z 1974 r. zatytułowany Television Traffic - A One-Way Street? Jego autorzy, Kaarle Nordenstreng i Tapio Varis, przebadali ramówki stacji telewizyjnych w 50 krajach, by empirycznie udokumen- 
tować źródła i kierunki transgranicznej wymiany ${ }^{11}$. W konkluzji przedstawili znaną diagnozę jednokierunkowego ruchu odbywającego się pomiędzy Zachodem a resztą świata, zaś swoje ustalenia zilustrowali prostą grafiką (zob. Ilustracja 1). Wnioski z raportu Nordenstrenga i Varisa znalazły potwierdzenie w badaniach przeprowadzonych przez UNESCO w kolejnej dekadzie ${ }^{12}$.
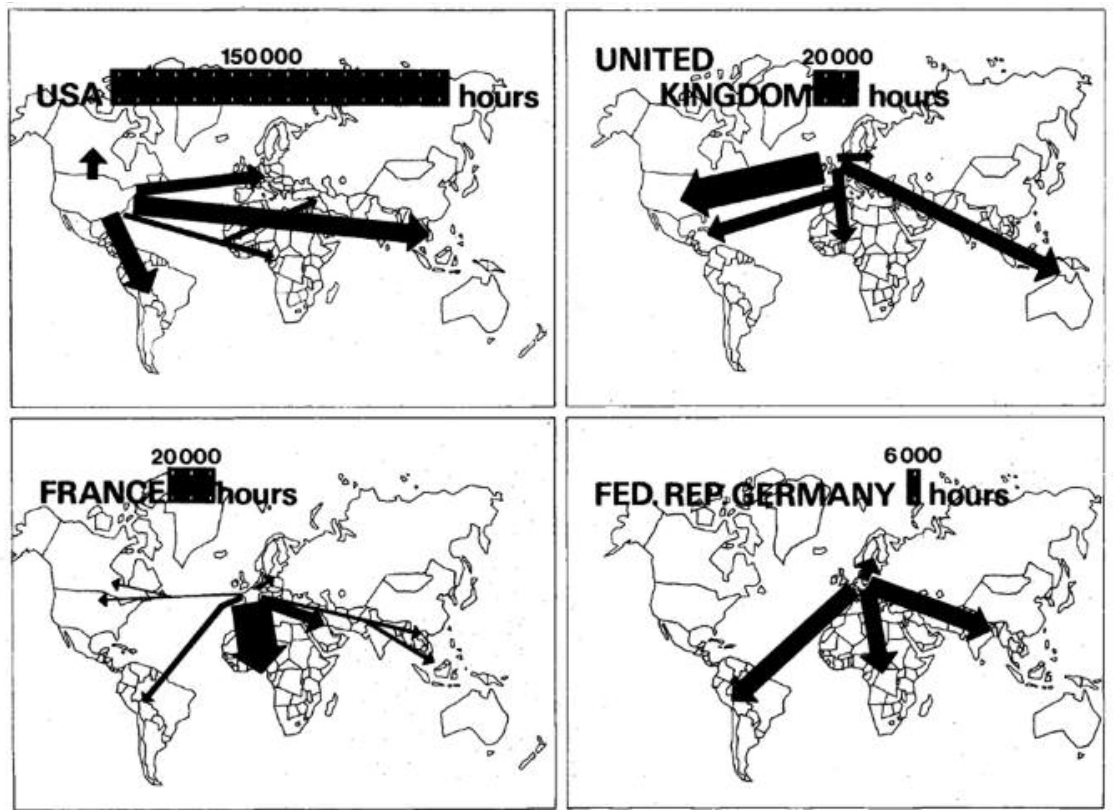

Ilustracja 2. Schematy dystrybucji treści głównych eksporterów na początku lat 70. XX w. ukazujące roczny eksport programów telewizyjnych w godzinach; grubość strzałek proporcjonalna do udziału danego państwa w światowym eksporcie. Źródło: K. Nordenstreng i T. Varis, dz. cyt., s. 30.

To stanowisko - choć naznaczone definicyjnymi trudnościami odnoszącymi się do narodowego pochodzenia koprodukcji czy programów informacyjnych ze wstawkami w postaci obcego materiału - dostarczyło empirycznych podstaw do sformułowania mocnych tez o kierunku i natężeniu międzynarodowych przepływów na rynku telewizji. Podobne wnioski przyniosły ważne badania Elihu Katza i George'a Wedella, opisane w 1977 r. w pracy Broadcasting in the Third World: przepływ programów i formatów rozrywkowych jest niemal całkowicie jednokierunkowy, a jeszcze wyraźniej jednokierunkowy jest przepływ wiadomości ${ }^{13}$. Choć ich ocena kulturowego oddziaływania eksportu telewizyjnego została sformułowana bardzo ostrożnie, Katz i Wedell nie mieli wątpliwości, że kraje rozwijające się (przynajmniej w latach 70.) były strukturalnie zależne od taniego importu ze Stanów Zjednoczonych oraz od zhomogenizowanej kultury popularnej kopiowanej lub pożyczanej od zachodnich nadawców ${ }^{14}$.

W latach 70. główną podstawą metodologiczną międzynarodowych badań nad telewizją była analiza ramówek. Równocześnie jednak badania te były wyrazem krytycznej dyskusji na temat rodzącego się wówczas globalnego ładu. W ekstremalnej wersji jednokierunkowy przepływ treści jest jednym z elementów imperialistycznego planu będącego kontynuacją długiej historii dominacji politycznej 
i gospodarczej. Telewizja funkcjonowała jako mikrokosmos odzwierciedlający ogólną prawdę: państwa rozwijające się nadal pozostawały pod dominacją, przy czym dochodziło do niej przy użyciu środków gospodarczych, politycznych i kulturowych. Ten sposób oglądu, nazwany później Modelem Globalnych Skutków (Global Effects Model) ${ }^{15}$, był niewątpliwie produktem swoich czasów - zimnowojennego konfliktu i niepokojów politycznych związanych z dekolonizacją, postkolonialnymi kwestiami państwowo-narodowościowymi i pojawieniem się w ONZ i UNESCO bloku państw niezaangażowanych. Jak zauważył Jean Chalaby, pogląd ten miał swoje źródło również w dialektyce marksistowskiej: przenosił [on] marksistowska interpretację odwiecznej walki klas na grunt relacji miejsca i kultury ${ }^{16}$.

Badania nad eksportem programów telewizyjnych koncentrowały się na dys trybu cji, a nie recepcji treści. Podobnie jak dzisiejsze analizy oferty programowej Netfliksa pokazujące mizerny udział programów lokalnych w katalogach tworzonych dla poszczególnych krajów, analizy pochodzące z lat 70. pomagały określić, ile amerykańskich produkcji znalazło się w programach telewizyjnych na całym świecie, ale już nie to, jak bardzo były one eksponowane i popularne oraz jakie było ich oddziaływanie kulturowe. Nie potrafiły też wyjaśnić, jaką rolę telewizja amerykańska odgrywała w życiu codziennym zagranicznych widzów. Dlatego wielu badaczy zaczęło podważać koncepcję imperializmu kulturowego jako recepcyjną ,teorię magicznego pocisku” i wiążące się z nią romantyczne wyobrażenie narodu jako oblężonej twierdzy, w której schroniła się kulturowa czystość ${ }^{17}$. Chris Barker stwierdził wręcz, że imperializm kulturowy stawał się koncepcją coraz bardziej nieadekwatna, jeżeli miałby stużyć zrozumieniu telewizji w jej współczesnych uwarunkowaniach ${ }^{18}$. Tymczasem Joseph Straubhaar ${ }^{19}$ oraz John Sinclair, Liz Jacka i Stuart Cunningham ${ }^{20}$ zaproponowali rewizję poprzednich ustaleń, podkreślając skalę międzyregionalnej wymiany handlowej na rynku telewizyjnym, szczególnie w Ameryce Łacińskiej. Ich badania dowiodły, że w wielu państwach treści importowane zastępowano produkcjami lokalnymi w miarę rozwoju krajowych systemów medialnych, a zatem materiały ze Stanów Zjednoczonych nie były dominacyjnym monolitem, jak pierwotnie sądzono. W obliczu tych nowych danych niektórzy badacze zaczęli postrzegać treści importowane z USA jako swego rodzaju telewizyjna zapchajdziurę, która można wypetnić luki w programie ${ }^{21}$, a nie niepowstrzymaną siłę kulturowej dominacji.

Przytaczając powyższe argumenty, chcę po prostu przypomnieć oczywistą prawdę, że siła eksportu nie przekłada się bezpośrednio na siłę kultury. Jednocześnie, przynajmniej niektóre aspekty tezy o imperializmie kulturowym pozostają istotne dla zrozumienia, jak odbiorcy na świecie postrzegają cyfrowe usługi medialne takie jak Netflix. Dominacja amerykańskich mediów pozostaje bowiem empirycznym faktem, z którym trzeba się liczyć; dowodzi tego oferta programowa Netfliksa. Obawy związane z jednokierunkowym przepływem treści nigdy nie odeszły w zapomnienie, a nierówności na rynku telewizji są aktualnym i poważnym problemem, niezależnie od tego, jak będziemy tłumaczyć ich oddziaływanie kulturowe. Widzowie nadal chcą oglądać telewizję w ojczystym języku (i narzekają, jeżeli nie zagwarantuje się im takiej możliwości), a w wielu państwach nadal istnieją regulacje, które mają chronić lokalne treści i pielęgnować lokalne narracje. Wszystko wskazuje więc na to, że podstawowe warunki, w których zrodziły się obawy opinii publicznej dotyczące jednokierunkowości przepływu, zasadniczo pozostają aktualne. 
Tę jawną sprzeczność między niedostatkami teorii jednokierunkowego przepływu i utrzymującym się niepokojem twórców polityki medialnej starannie przeanalizowała Milly Buonanno. Choć przeprowadzona przez badaczkę analiza programów europejskich stacji telewizyjnych w latach 1990-2010 dowiodła, że połowa filmów i seriali wyemitowanych w telewizji naziemnej na terenie Europy pochodziła z Ameryki Północnej, Buonanno niezwykle ostrożnie podchodzi do formułowania sądów na jej podstawie. Sięgnijmy po fragment znakomitej książki The Age of Television, która oferuje zniuansowany obraz dynamiki eksportu i zawiera pewne zastrzeżenia dotyczące tezy o dominacji USA: Jeżeli chodzi o podaż, być może rzeczywiście „media sa amerykańskie” ${ }^{22}$, jednak temu twierdzeniu musza towarzyszyć pewne rozróżnienia (...) nie dotyczy to telewizji w jej ogólnym wymiarze, lecz filmów znajdujacych się w programie telewizyjnym, i nie jest niezmiennym stanem rzeczy, lecz podlega wahaniom w czasie i przestrzeni. Po stronie odbiorców sprawy maja się jednak inaczej. (...) Nie musimy przywiązywać się do teorii, że publiczność nasyciła się amerykańska telewizją, nawet jeżeli to prawda. Powinniśmy raczej przyjrzeć się strukturalnemu charakterowi luki między podaża a popytem na zagraniczny produkt, której powstanie nie byto przypadkowe ${ }^{23}$.

Podążając za tą logiką, dostrzegamy, że wyjaśnienie kwestii międzynarodowych przepływów na rynku telewizyjnym jest trudne nie tyle ze względu na konieczność opowiedzenia się za tym czy innym paradygmatem (globalizacja versus imperializm kulturowy), ile z uwagi na potrzebę starannego rozróżnienia między dystrybucją a recepcją, strukturą ekonomiczną a siłą sprawczą widzów/klientów, a także dynamiką charakterystyczną dla poszczególnych typów programów. Innym ważnym spostrzeżeniem Buonanno jest to, że chociaż paradygmat imperializmu kulturowego utracit kluczowa pozycję w obszarze teorii eksplicytnych, nadal trzyma się mocno na poziomie teorii implicytnych, które leża u podstaw dyskursu publicznego i potocznych rozmów ${ }^{24}$. Wiele mniejszych narodów wciąż lęka się widma imperializmu kulturowego, nawet jeżeli nazywa je inaczej i niezależnie od tego, czy źródłem przeczuwanego zagrożenia są Stany Zjednoczone, Francja, Indie, Japonia, Chiny czy Korea.

Co to ma wspólnego z Netfliksem? Nie da się zrozumieć stosowanych na świecie rozwiązań politycznych dotyczących usług internetowych, zwłaszcza typu SVOD (subscription video on demand - wideo na żądanie w ramach płatnej subskrypcji), nie wyciągając wniosków z debaty o imperializmie kulturowym. Wraz ze zdobywaniem przez serwisy SVOD coraz większego udziału w rynku telewizyjnym w wielu krajach rosną obawy dotyczące jednokierunkowego przepływu treści na niepodlegających regulacji platformach, w większości zarejestrowanych w USA. Wiąże się z tym odrodzenie protekcjonizmu kulturowego i wzmocnienie regulacyjnej roli państwa narodowego ${ }^{25}$. Pojawienie się telewizji internetowej dość nieoczekiwanie za ostrzyło prowadzone od dawna spory o przepływy treści telewizyjnych w ogóle, właśnie ze względu na jej zwiększone możliwości w zakresie „zdalnego sterowania” ofertą programową.

\section{Katalogi Netfliksa a unijna polityka medialna}

Niesłabnące przywiązanie Unii Europejskiej do koncepcji „wyjątkowości kultury", wedle której, jak ujął to były francuski prezydent François Mitterand, wytwory ducha nie sa jedynie towarami, a elementy kultury nie sa wytacznie domena 
handlu, ukształtowało europejską politykę medialną. Nadrzędnym celem głównej unijnej regulacji prawnej w zakresie mediów, czyli Dyrektywy o audiowizualnych usługach medialnych z 2010 r. ${ }^{26}$, jest pielęgnowanie europejskiej przestrzeni audiowizualnej. Zastąpiwszy dyrektywę Telewizja bez granic z 1989 r., nowe prawo ma gwarantować łatwy przepływ treści między państwami członkowskimi, a równocześnie dostęp do filmów i programów telewizyjnych w językach lokalnych i narodowych: niderlandzkie filmy dla Holendrów, hiszpańska telewizja dla Hiszpanów. W związku z tym obecna dyrektywa wyznacza kwotę minimalną dla ofert programowych (sprowadzającą się do tego, że przynajmniej połowa emitowanych treści musi pochodzić z Europy), którą poszczególne państwa członkowskie mogą podnosić we własnym zakresie.

Unijna dyrektywa audiowizualna (gdy piszę te słowa nowelizacja jest w opracowaniu ${ }^{27}$ ) traktuje usługi na żądanie bardzo oględnie, wspominając jedynie o ogólnej powinności ,promowania” europejskich produkcji ${ }^{28}$. Stworzenie bardziej szczegółowych przepisów służących realizacji tego celu (na przykład przez minimalny udział procentowy lokalnych treści w katalogu, dodatkowe opłaty dla nadawców albo wymagania inwestycyjne) pozostawiono państwom członkowskim. W wielu z nich oferta programowa serwisów VOD musi dziś spełniać warunki zakładające określony udział lokalnych treści, przy czym jego wartość procentowa różni się znacznie w poszczególnych krajach. Na przykład firmy zarejestrowane we Francji, Austrii i na Litwie muszą przeznaczyć przynajmniej połowę miejsc w katalogu na treści europejskie, podczas gdy te z Czech, Malty i Słowenii mają do osiągnięcia dużo niższy, dziesięcioprocentowy próg ${ }^{29}$. Zasadniczo państwa Europy Środkowej i Wschodniej wybierają raczej niższe wymogi procentowe lub w ogóle z nich rezygnują, a te z zachodniej części Unii wolą wyższe normy.

Niezależnie od wymogów dotyczących samego udziału programów europejskich w katalogach serwisów VOD niektóre kraje wprowadziły również szczegółowe przepisy regulujące sposób, w jaki treści są prezentowane widzom ${ }^{30}$. W Rumunii każdy tytuł musi być opatrzony informacją o kraju pochodzenia. W Polsce prawo zobowiązuje serwisy do określonego sposobu promocji europejskich treści w zwiastunach, na stronach domowych i w katalogach. Estońskie przepisy nakazują, by serwisy VOD eksponowały nowsze produkcje europejskie, od których premiery upłynęło nie więcej niż pięć lat. Regulacje te tworzą kolejny poziom złożoności funkcjonującego już w wielu państwach Unii wymogu minimalnego udziału treści europejskich w ofercie programowej.

Największym zwolennikiem regulacji polityki kulturalnej w UE jest Francja, która wprowadziła system wzajemnie powiązanych przepisów mających chronić narodowe zwyczaje, język i media przed wpływem treści anglojęzycznych. Francja podniosła minimalne wymogi unijne dotyczące treści, tak że obecnie francuskie produkcje muszą stanowić 40 proc. programów emitowanych w telewizji i radiu, a nie mniej niż 60 proc. treści oferowanych w systemie na żądanie ma pochodzić z Europy. Co więcej, na dostawców telewizji FTA (free-to-air - telewizja, której odbieranie nie wymaga subskrypcji), płatnej telewizji i usług TVOD (transactional video on demand - transakcyjne wideo na żądanie) nałożono obowiązek inwestowania części przychodów w europejskie i francuskie produkcje, a dystrybucja filmów poza kinami podlega ściśle określonej chronologii ${ }^{31}$. Francja wprowadziła 
również szczegółowe zasady eksponowania treści w serwisach VOD. Obecne prawo stanowi, że strona domowa / pierwsza strona dostawcy ustug musi w znacznej części zawierać informacje o europejskich lub francuskojęzycznych produkcjach, pokazując nie tylko tytuły, lecz także materiały wizualne i zwiastuny ${ }^{32}$. Jednak przepisy te mają zastosowanie tylko w przypadku usługodawców z siedzibą na terenie Francji, nie odnoszą się natomiast do firm z zagranicy świadczących usługi dla publiczności francuskiej. W dyrektywie o audiowizualnych usługach medialnych została wprowadzona ,zasada kraju pochodzenia”, w myśl której usługodawców obowiązują przepisy państwa, w którym mają siedzibę. Dlatego europejska filia Netfliksa z siedzibą w Niderlandach musi spełniać jedynie tamtejsze, mało restrykcyjne wymogi dotyczące treści europejskich, niezależnie od tego, jak wielu subskrybentów ma we Francji. Tym samym prawo zachęca usługodawców do rejestrowania działalności w tych państwach członkowskich UE, które nie wykazują silnych tendencji regulacyjnych.

Członkowie europejskich organów regulacyjnych doskonale zdają sobie sprawę z problemu, który skutkuje różnicami w poszanowaniu unijnych zasad dotyczących treści w poszczególnych państwach członkowskich. Podjęto więc starania, by przez zharmonizowanie krajowych przepisów ujednolicić sposób działania regulacji. W 2014 r. Komisja Europejska ogłosiła, że w ramach strategii jednolitego rynku cyfrowego rozpoczną się konsultacje w sprawie nowej wersji dyrektywy audiowizualnej. Nastąpiły trzy miesiące intensywnego lobbingu: największe europejskie przedsiębiorstwa telekomunikacyjne i firmy technologiczne z USA (w tym Netflix i Verizon) przekonywały do utrzymania status quo, a przedstawiciele branży telewizyjnej i filmowej (oraz wielu państw członkowskich) - do wzmocnienia regulacji. Szczególnie aktywnym członkiem debaty była Francja, która postulowała wprowadzenie nowego progu minimalnego udziału treści europejskich, by promować różnorodność kulturową i chronić przemysł audiowizualny w Europie przed nieuczciwą konkurencją ze strony firm amerykańskich. W formularzu konsultacji KE francuski rząd skrytykował również tendencję ,niektórych pozaeuropejskich przedsiębiorstw" do rejestrowania działalności w państwach członkowskich, które mają najłagodniejsze przepisy: Taka relokacja, szczególnie łatwa do przeprowadzenia w przypadku ustug niematerialnych, jest forma tzw. forum shopping [wyboru jak najkorzystniejszej jurysdykcji] i ostatecznie odbywa się kosztem łańcucha wartości produktów europejskich. W rezultacie nadawcy z siedziba we Francji, których obowiazuja ambitne przepisy, majace na celu wspieranie przemystu audiowizualnego, ochronę twórców oraz oferowanie widzom treści zróżnicowanych i wysokiej jakości, doświadczają bezpośredniej i nieuczciwej konkurencji ze strony ustugodawców zarejestrowanych za granica, niepodlegajacych tym samym regulacjom, a osiagajacych zyski z działalności na tym samym rynku ${ }^{33}$.

Nie jest niczym zaskakującym, że Netflix ostro sprzeciwił się tym propozycjom. W opinii zgłoszonej do KE firma uprzedzała, że sztywne wymogi ilościowe moga doprowadzić do zduszenia rynku audiowizualnych ustug medialnych na żadanie i że obowiazek dystrybucji określonych treści celem spetnienia wymogów ilościowych może sprawić, że nowe podmioty będa miały trudności z osiagnięciem zrównoważonego modelu biznesowego. Netflix udzielił nawet Brukseli darmowej porady w zakresie tworzenia polityki medialnej, sugerując, że unijna polityka audiowizualna powinna koncentrować się na zachęcaniu do produkcji europejskich 
treści, a nie narzucaniu wymogów ilościowych (...) ustugodawcom, którzy moga mieć kłopot z ich spetnieniem ${ }^{34}$.

Po długim namyśle Komisja Europejska ostatecznie podzieliła stanowisko Francji. Propozycja nowego pakietu przepisów o audiowizualnych usługach medialnych, ogłoszona w marcu 2016 r. pod hasłem Prawo medialne na XXI wiek, zawierała istotne nowe wymogi regulacyjne, które zapewne zmienią pejzaż usług audiowizualnych w Europie ${ }^{35}$. Najbardziej kontrowersyjny jest wymóg dwudziestoprocentowego udziału treści europejskich w katalogach serwisów VOD i SVOD, (zwiększony później do 30 proc. przez Parlament Europejski), którego wprowadzenie ma stworzyć lepsze warunki promocji utworów europejskich. Co ważne, nowe przepisy miałyby zastosowanie niezależnie od kraju pochodzenia: zarówno duże serwisy europejskie, jak i te spoza UE, takie jak Netflix, musiałyby spełniać te same wymogi, chcąc prowadzić działalność w państwach członkowskich. Nowa dyrektywa audiowizualna zawiera także zapis dotyczący systemów rekomendacji stosowanych przez cyfrowe platformy wideo. Teraz treści europejskie musiałyby mieć zagwarantowaną dobrą widoczność w katalogach, nawet jeżeli oznaczałoby to konieczność zmiany algorytmów. W ten sposób miałyby być traktowane priorytetowo. Wymóg takiego automatycznego eksponowania stanowi znaczącą zmianę; to sygnał, że KE chce uniemożliwić usługodawcom obchodzenie norm ilościowych przez zakup licencji na dystrybucję tanich produkcji europejskich niskiej jakości, które by następnie ukrywano głęboko w czeluściach katalogów.

Unijne organy regulacyjne po prostu uznały za oczywiste, że użytkownicy Netfliksa i innych serwisów tego typu nie mają do czynienia z tradycyjnym katalogiem - jako listą czy harmonogramem, lecz raczej z sekwencją interaktywnych, spersonalizowanych rekomendacji, uporządkowanych algorytmicznie na podstawie danych dotyczących programów obejrzanych wcześniej, czynników demograficznych i lokalizacji danego użytkownika. W związku z tym, że automatyczne rekomendacje w dużym stopniu warunkują wybory użytkowników, sposób generowania takich systemów niewątpliwie stanowi istotne zagadnienie, które należy uwzględnić w przepisach dotyczących polityki kulturalnej. Jeżeli druga z przywołanych zasad zostanie wdrożona, wymusi zmiany w sposobie działania algorytmów Netfliksa, które obecnie generują rekomendacje na podstawie historii korzystania z serwisu przez danego użytkownika.

Oczywiście Netflix sprzeciwił się regulacjom dotyczącym filtrowania treści, twierdząc, że postulowane rozwiązania są „,niekompatybilne” ze sposobem, w jaki ludzie korzystają z usług SVOD, i że uniemożliwiłyby one dalsze tworzenie rekomendacji zgodnych z zainteresowaniami użytkowników. Wcześniej firma dowodziła przed KE, że spersonalizowane rekomendacje są najlepszą promocją europejskich utworów, właśnie dlatego, że opierają się na wykazanych wcześniej preferencjach. Dzięki temu oferują więcej programów z Europy osobom, które z uwagi na swoje upodobania takich treści oczekują. Jak ujęli to przedstawiciele Netfliksa, podejście oparte na personalizacji konsumenckiej pozwala na udostępnienie większej liczby europejskich programów subskrybentom zainteresowanym treściami tego typu i pomaga im odnaleźć europejskie produkcje, a zatem promuje je i tworzy samonapędzajacy się mechanizm popytu i podaży ${ }^{36}$.

Mówiąc o „samonapędzającym się mechanizmie popytu i podaży”, Netflix może nieco ubarwiać rzeczywistość, ale uwaga o działaniu rekomendacji nie jest bezza- 
sadna. W istocie w serwisach SVOD katalog to zaledwie prosty zbiór treści, z których na podstawie algorytmów są komponowane konkretne zestawienia; rzadko jest on widoczny dla użytkowników w całości. Algorytm jest ważnym elementem tego procesu. Jednocześnie trudno odmówić słuszności argumentom zwolenników regulacji, którzy twierdzą, że on także winien zostać nią objęty. Pojawiające się w tym względzie napięcie odzwierciedla płynność granic dzisiejszych debat na temat polityki medialnej, które dotyczą nie tylko tego, jak i w jakim stopniu regulować rynek mediów, lecz także c o poddać regulacji (które obiekty, technologie i praktyki zaliczają się do „mediów”). Wydaje się, że Unia Europejska zmierza ku temu, by traktować algorytmiczne rekomendacje jako oddzielny system medialny, a przynajmniej jako odpowiedni przedmiot regulacji.

Jak wspomniałem, nowe przepisy nie zostały jeszcze uchwalone. Niemniej sam fakt, że proponowane zmiany są omawiane na najwyższym szczeblu, świadczy o tym, z jakim przejęciem podchodzi się do tego problemu w Europie, gdzie kwestie suwerenności narodowej, różnorodności kulturowej, a także imperializmu kulturowego nadal odgrywają istotną rolę. Poszerzając zakres regulacji o zagadnienie widoczności nowych treści, dyrektywa audiowizualna zapowiada nowe podejście do polityki medialnej, próbę zaktualizowania istniejących modeli regulacyjnych tak, by odpowiadały bardziej złożonej, ukontekstowionej rzeczywistości dystrybucji cyfrowej i sugeruje pewne rozwiązania techniczne, które przyszłe rządy będą mogły wykorzystać do ingerencji w system ekonomiczny mediów cyfrowych.

\section{Casus Kanady}

Interwencjonistyczna postawa Unii Europejskiej warta jest uwagi jako odstępstwo od ogólnego deregulacyjnego trendu w światowej polityce medialnej ostatnich dekad. Stosunkowo niewiele rządów ma środki i chęci, by sięgać po regulacyjne rozwiązania prawne. Są kraje, które nie nakładają na platformy cyfrowe wymogów dotyczących udziału rodzimych treści, bo uniemożliwiają to zawarte wcześniej umowy handlowe - na przykład Australia przehandlowała to prawo, negocjując bilateralną umowę o wolnym handlu z USA w 2004 r.

Interesującym przypadkiem jest Kanada - państwo średniej wielkości pod względem zaludnienia, z długą tradycją polityki kulturalnej chroniącej dwujęzyczną przestrzeń medialną.

Kanada ma finansowane $\mathrm{z}$ budżetu państwa media publiczne i funkcjonujące od dawna systemy państwowego wsparcia dla produkcji kinowej i telewizyjnej, a także system kwotowej ochrony kanadyjskich treści (CanCon), obejmujący m.in. wymóg, by serwisy VOD włączały kanadyjskie filmy do swoich katalogów ${ }^{37}$. Netflix jest tam obecny stosunkowo długo, bo od 2010 r. Szacuje się, że z serwisu korzysta 53 proc. kanadyjskich gospodarstw domowych, w których głównym językiem jest angielski ${ }^{38}$, co czyniłoby Netflix raczej medium głównego nurtu niż niszowym. Mimo to, jako usługa cyfrowa, Netflix nie musi inwestować w kanadyjski przemysł audiowizualny na takich zasadach, jak nadawcy telewizji i płatnej telewizji. Kanadyjscy lewicowi postępowcy opowiadają się za poddaniem Netfliksa ściślejszej regulacji, widząc w tym sposób na ochronę kultury kanadyjskiej w obliczu nieuczciwej konkurencji ze strony serwisów OTT. Raport think-tanku Canadian Centre for Policy Alternatives dobrze podsumowuje to stanowisko: Kanada stawała już w obliczu 
punktów zwrotnych, jeśli chodzi o rynek medialny, a rząd w Ottawie dowiódt, że potrafi zadbać o to, by kanadyjska produkcja kulturalna otrzymywała ciagłe wsparcie. Na przyklad w latach 30. ubiegłego wieku stworzyliśmy CBC [Canadian Broadcasting Corporation - główny publiczny nadawca radiowo-telewizyjny], by przeciwdziałać dominacji anglojęzycznego radia amerykańskiego. W latach 60., kiedy Kanadę zalały amerykańskie programy telewizyjne, wypracowaliśmy nowe przepisy dotyczace kanadyjskich treści. Dziś znów chodzi o dominację, tym razem w Internecie, głównie ze strony amerykańskich serwisów OTT, które stały się nie tylko swoimi własnymi sieciami dystrybucyjnymi, lecz także twórcami nowych mediów ${ }^{39}$.

Również w tym wypadku zagadnienie regulacji treści zostaje powiązane z kwestiami suwerenności narodowej: jeżeli Kanada nie podejmie w trybie pilnym działań, żeby uregulować internetowe usługi telewizyjne, grozi jej utrata kontroli nad swoim systemem nadawczym i spowodowanie powaznych szkód w produkcji i dostarczaniu kanadyjskich treści kulturowych. Autorzy raportu porównują tę sytuację do epoki braku regulacji na rynku radiowym w latach 30. $i$ 40. XX w., kiedy kanadyjskie fale radiowe byly zdominowane przez programy amerykańskie, a my byliśmy tylko zamiejscowym oddziałem kultury amerykańskiej ${ }^{40}$. Wizja Netfliksa jako kolejnej amerykańskiej firmy medialnej wdzierającej się siłą w narodową przestrzeń audiowizualną nie jest obca Kanadyjczykom. Jak ujęła to niedawno dziennikarka „Globe and Mail”: Nawyki Kanadyjczyków w przestrzeni cyfrowej wypompowują z systemu miliony dolarów, ponieważ środki wydawane na reklamy, abonament Netfliksa czy zakupy w Amazonie ostatecznie odptywaja do Kalifornii. Tymczasem kanadyjskim treściom grozi utonięcie $w$ internetowym oceanie ${ }^{41}$.

Tabela 1. Płatne subskrypcje usług OTT w Kanadzie (szacunki w populacji anglojęzycznej)

Netflix $\quad 53 \%$

\begin{tabular}{ll}
\hline CraveTV & $9 \%$ \\
\hline Amazon Prime Video & $5 \%$ \\
\hline Sportsnet Now & $5 \%$
\end{tabular}

Źródło danych: Media Technology Monitor Survey, cyt. za. S. Robertson, dz. cyt.

Agitujący po drugiej stronie sceny politycznej kanadyjscy konserwatyści są, ogólnie rzecz ujmując, sceptyczni wobec systemu kwotowego i regulacji mediów ${ }^{42}$. Dowodzą, że nakładanie nowych podatków czy obowiązków na dostawców usług internetowych nie jest koniecznym warunkiem popularności kanadyjskich treści wysokiej jakości i że takie regulacje tamują rozwój innowacji cyfrowych i wolnych rynków (postrzeganych jako najlepsze narzędzie tworzenia kultury). Podobnie jak postępowcy, kanadyjscy konserwatyści również znaleźli powody, by włączyć sprawę Netfliksa do debaty politycznej. Podczas kampanii przed wyborami do parlamentu w 2015 r. premier Stephen Harper opublikował na Twitterze materiał wideo z wystąpieniem, w którym obiecuje, że - w przeciwieństwie do Justina Trudeau - nigdy nie opodatkuje usług OTT. Kocham filmy i programy telewizyjne napisał wtedy. Jestem w 100 proc. przeciwko podatkowi dla \#Netflix. Zawsze bytem, zawsze będę \#NoNetflixTax.

W latach 2013-2014 Canadian Radio-Television and Telecommunications Commission przeprowadziła konsultacje społeczne pod nazwą Let's Talk TV, 
chcąc zdobyć wiedzę, która pomogłaby w kształtowaniu krajowej polityki medialnej. Przesłuchania odbyły się w 2014 r., a o informacje poproszono przedstawicieli Netfliksa. Kierownictwo firmy odmówiło jednak ujawnienia wrażliwych danych handlowych, które chciała poznać komisja, takich jak liczba subskrybentów Netfliksa w Kanadzie i konkretna wartość finansowa jego inwestycji w kanadyjskie treści, ograniczając się do stwierdzenia, że kanadyjskie treści maja się świetnie w Netflix. Chcąc skarcić platformę za brak współpracy, komisja wykreśliła jej stanowisko z publicznych akt procesu konsultacji. Sprawa, która wówczas odbiła się w Kanadzie szerokim echem, obrazuje nonszalancką postawę Netfliksa wobec niektórych krajowych organów regulujących rynek medialny. Ostatecznie Netflix nie miał obowiązku stosować się do zasad ustalonych przez kanadyjską komisję i - ze względu na własną korzyść - zrezygnował z udziału w konsultacjach ${ }^{43}$.

Stosunki między Netfliksem a kanadyjskimi organami regulacyjnymi z czasem stały się jeszcze bardziej problematyczne. W 2017 r., ogłaszając nowe zalecenia rządowe dotyczące ochrony kanadyjskich treści, minister dziedzictwa narodowego Mélanie Joly wspomniała o dwóch ważnych ustaleniach związanych z działalnością platformy. Po pierwsze, Netflix i rząd kanadyjski zawarły umowę, zgodnie z którą firma utworzy w Kanadzie swoją bazę produkcyjną i w ciągu pięciu lat zainwestuje 500 mln dolarów kanadyjskich w krajową produkcję filmową i telewizyjną. Netflix utrzymywał, że chodzi o nowe fundusze, nieobejmujące wcześniej przeznaczonych na ten cel środków, jednak niektórzy obserwatorzy podeszli do tego zapewnienia z rezerwą, inni zaś zastanawiali się, czy będą w ten sposób finansowane produkcje przeniesione z USA, co pozwoliłoby firmie wykorzystać niższe koszty produkcji w Kanadzie. Choć Netflix zarzekał się, że jego kanadyjska inwestycja jest motywowana przekonaniem, że Kanadyjczycy tworza świetne historie nadające się do dystrybucji globalnej ${ }^{44}$, nie przekonał swoich krytyków ${ }^{45}$. Po drugie rząd podjął decyzję, by wstrzymać plany nałożenia podatku od sprzedaży na cyfrowe serwisy streamingowe. Oba ustalenia zostały podane do wiadomości publicznej tego samego dnia i choć zarówno Netflix, jak i rząd kanadyjski podkreślały, że nie są one powiązane i że fundusze na produkcję nie zostały zagwarantowane w zamian za ulgę podatkową, ta zbieżność wzbudziła niemałe wątpliwości.

Porównanie debat nad polityką medialną w Unii Europejskiej i Kanadzie ukazuje zarówno pewne różnice, jak i podobieństwa. W przeciwieństwie do UE, Kanada nie postuluje narzucenia Netfliksowi ilościowych norm dotyczących katalogów, choć kwestia udziału kanadyjskich treści w ofercie platformy pozostaje wielce kontrowersyjna. Obecna polityka audiowizualna Kanady kładzie nacisk na wsparcie dla tworzenia, odkrywania i eksportu kanadyjskich treści, proponując bardziej strategiczny model subwencjonowania produkcji opowiadających kanadyjskie historie, podczas gdy w Europie przyjęto model kwotowy. „Odkrywanie” kojarzy się z dystrybucją, wyszukiwaniem i algorytmicznym filtrowaniem tytułów - czyli ze wszystkimi aspektami charakterystycznymi dla ery Netfliksa. Podobnie jak Unia Europejska, Kanada koncentruje się na dystrybucji cyfrowej, starając się dostosować swoją długoletnią tradycję polityki medialnej do nowego zjawiska. Czas pokaże, czy to wystarczy, by zadowolić kanadyjskich twórców i zwolenników polityki kulturalnej. 


\section{Czy widzowie rzeczywiście chcą lokalnych treści (w Netfliksie)?}

Przyjrzeliśmy się szczegółowo stanowiskom przedstawicieli organów prawodawczych i rzeczników polityki medialnej, ale co z widzami? Jakie jest ich zdanie w kwestii lokalnych treści? Opinie publiczności nie wybrzmiewają w debatach na ten temat, dlatego trudno stwierdzić, jakiego stopnia lokalności w telewizji chcieliby widzowie i jak postrzegają w tym kontekście różne rodzaje usług telewizyjnych.

Rozważając ten problem, warto wrócić do raportu Television Traffic - A One-Way Flow oraz załączonych do niego uwag Elihu Katza. Niektóre spostrzeżenia Katza, pochodzące przecież sprzed ponad 40 lat, są bowiem niezwykle aktualne w odniesieniu do Netfliksa. Badacz rozpoczyna od uwagi, że krytyka amerykańskiej czy europejskiej dominacji w radiofonii i telewizji opiera się na pewnych założeniach dotyczacych wartości i że założenia te warto określić wprost: Przede wszystkim zakłada się, że twórczość narodowa-czyli rodzime produkcje-ma pozytywna wartość. A przecież można by się z tym nie zgodzić - można argumentować, że państwa narodowe nie powinny dażyć do tworzenia własnej kultury ani kontynuować swojej zaściankowej tradycji. Może warto być bardziej kosmopolitycznym? W każdym razie na pewno taniej jest pozwolić, by to Wuj Sam zająt się robota. Wiąże się z tym pytanie, jakiego rodzaju swobodnego przeplywu informacji chcielibyśmy. Przedstawionym tu badaniom przyświeca założenie, że ideałem, do którego należy dązyć, jest egalitarny przeptyw informacji we wszystkich kierunkach. Ale być może niektórym odpowiadałby obecny, bardziej jednokierunkowy przeptyw, nawet jeśli wytacznie dlatego, że wola nie ingerować w informacje. Może globalna wioska nie jest taka zła? Może szybciej doczekamy się schytku państwa narodowego, jeżeli telewizja i inne media kulturalne zostana zhomogenizowane! Może nie będzie tylu konfliktów między narodami, jeśli te odnajda wspólny grunt dzięki serialowi „Peyton Place”. Być może widzowie na catym świecie naprawdę wola ,,Bonanzę" od lokalnych produktów kulturalnych? ${ }^{46}$

Wystarczy wymienić Peyton Place (1964-1969) i Bonanzę (1959-1973) na Stranger Things (2016-), by zrozumieć, że argumenty Katza odnoszą się do przypadku Netfliksa. Założenie, że publiczność w o li zobaczyć w Netfliksie filmy ze swoich krajów niż z Hollywood, budzi wątpliwości. Przecież możliwa jest także sytuacja, w której szerzej rozumiany system medialny danego kraju jest już ustrukturyzowany i uregulowany w taki sposób, że dostarcza znacznych ilości lokalnych treści za pośrednictwem istniejących kanałów nadawczych i płatnej telewizji. Kwestie, o których pisał Katz, ewidentnie pozostają nierozstrzygnięte.

Trudno tu uogólniać. W każdym kraju kwestia treści lokalnych przedstawia się inaczej. W rozdziale 4. przyglądaliśmy się sytuacji w Indiach, gdzie Netflix jest serwisem bardzo niszowym i gdzie nie toczy się debata o polityce medialnej w zakresie „,indyjskich treści w Netfliksie”. Indie mają swój bardzo dojrzały i prężny, komercyjny przemysł telewizyjno-filmowy, w którym język funkcjonuje jako naturalna bariera ochronna; nie ma więc faktycznej potrzeby, żeby Netflix dokładał swoją cegiełkę do istniejących zasobów narodowej autoreprezentacji. Sztandarowe, ,alternatywne" anglojęzyczne programy Netfliksa przyciągają tych indyjskich odbiorców, którzy i tak są nastawieni na zagraniczne treści. Wszyscy są mniej lub bardziej zadowoleni z tego układu, przynajmniej dopóki Netflix nie stanie się na tyle popularny, żeby zagrozić istniejącym podmiotom. Natomiast w krajach takich, jak Australia, 
Nowa Zelandia czy Wielka Brytania, amerykańska oferta programowa może - ze względu na język - w większym stopniu wypierać lokalne programy. Wielu Australijczyków, Nowozelandczyków, Brytyjczyków i Kanadyjczyków bez żalu żegna się z rodzimymi produkcjami i z otwartymi ramionami przyjmuje ich wysokobudżetowe, a też anglojęzyczne odpowiedniki firmowane przez Netfliksa.

Jak widać, debaty na temat polityki kulturalnej prowadzone w poszczególnych krajach znacznie się różnią. Potencjalny wpływ Netfliksa na rynki krajowe jest uwarunkowany przez ich wewnętrzną specyfikę. Sprawę ponadto komplikuje fakt, że zajmowane przez Netflix nis ze rynkowe są różne w różnych miejscach. W Stanach Zjednoczonych Netflix jest usługą pochodzącą z głównego nurtu, produktem użytkowanym przez klasę średnią, przystępnym cenowo i dostępnym dla większości osób, które mają w domu szybkie łącze internetowe. W innych częściach świata z serwisu korzysta znikoma część społeczeństwa albo robią to tylko przedstawiciele kosmopolitycznej klasy wyższej, których gusta nie muszą odzwierciedlać upodobań współobywateli (przypomnijmy, że firma wyraźnie kieruje swoją zagraniczną ofertę do ,anglojęzycznych elit” w poszczególnych krajach ${ }^{47}$ ). Inaczej rzecz ujmując, Netflix dostarcza usługi rozmaitym grupom użytkowników na świecie, a zarazem na różniące się między sobą rynki krajowe, dlatego też opinie organów regulacyjnych na temat sposobu działania tej platformy (wyrażające stopień poczucia zagrożenia) są tak zróżnicowane.

To wszystko ewokuje kilka ciekawych pytań dotyczących regulacji. Jeżeli Netflix funkcjonuje gdzieś jako serwis niszowy, obsługujący niewielką liczbę widzów, to czy nadal należy domagać się, żeby jego oferta programowa reprezentowała lokalny styl życia? Być może takie oczekiwania są z gruntu niesprawiedliwe. Kanadyjczycy - wiedząc, jak niewielu odbiorców mają w ich kraju europejskie serwisy SVOD specjalizujące się w kinie artystycznym (np. Mubi) - nie wymagają od nich przecież wspierania lokalnego przemysłu filmowego. Nowozelandczycy też nie oczekują, że chiński serwis oferujący materiały wideo na żądanie będzie wspierał ich produkcje tylko dlatego, że jest potencjalnie dostępny w Nowej Zelandii. Dlatego polityka medialna stworzona z myślą o konwergentnych rynkach często określa usługi medialne według kryterium ich zakresu i liczby odbiorców, a nie na podstawie sposobu dostarczania treści. Na przykład, przygotowując nową europejską dyrektywę audiowizualną, wyraźnie stwierdzono, że przepisy będą dotyczyły „mediów masowych”, a nie firm notujących mniejsze obroty, serwisów tematycznych czy małych i mikroprzedsiębiorstw. Ujmując globalną działalność Netfliksa całościowo, z pewnością nie można powiedzieć, by ta firma wykazywała niski obrót; jednocześnie w niektórych krajach jest on rzeczywiście niewielki. Czy to wystarczający powód, żeby objąć Netflix immunitetem mającym chronić go przed konsekwencjami regulacji? Czy definicje zakresu działalności stosowane przez organy regulacyjne powinny uwzględniać specyfikę obecności firmy w danym kraju, czy też jej działalność gospodarczą w ogóle? Oto niektóre z zagadnień polityki medialnej, które przypadek Netfliksa każe nam wziąć pod rozwagę.

W tym kontekście apele o to, by Netflix zachowywał się jak krajowy nadawca telewizyjny, mogą być nieco naiwne, a nawet kontrproduktywne. Idąc tropem poczynionych przed laty spostrzeżeń Elihu Katza, musimy pogodzić się z ewentualnością, że w skali globalnej wielu widzów woli House of Cards (2013-2018) od rodzimych programów (a raczej ceni sobie możliwość oglądania tego serialu oprócz 
rodzimych programów). Tak w każdym razie uważa Ted Sarandos, dyrektor ds. programowych Netfliksa. W 2014 r., zwracając się do analityków finansowych na spotkaniu podsumowującym wyniki kwartalne, Sarandos tak skomentował działanie zasady 80/20 w Europie Zachodniej, gdzie firma niedawno rozpoczęła działalność: O tym, że odpowiednio dobieramy proporcje, świadczy oglądalność mierzona w godzinach. We Francji $i$ w Niemczech ogladalność jest porównywalna do wyników otwarcia, które mieliśmy na wszystkich innych rynkach. A więc (...) konsumenci znajdują to, czego chca. Trudniej się zorientować, czy widzowie będa zainteresowani lokalnymi treściami w dluższej perspektywie czasowej. Sądzę, że w pierwszej chwili, gdy wchodzimy na nowy rynek, ludzie sa najbardziej podekscytowani tym, do czego wcześniej nie mieli dostępu. I tak „, Orange Is the New Black” byt najczęściej ogladanym serialem zarówno we Francji, jak $i$ w Niemczech - zreszta taka sytuacja miała miejsce na wszystkich naszych nowych rynkach. A więc mimo zróżnicowanych gustów (...) największa uwage przykut właśnie ten program ${ }^{48}$.

To, o czym mówi Sarandos, leży w interesie Netfliksa i nie należy zbytnio ufać uprawianemu przez niego PR-owi. Jednak nie powinniśmy także z góry odrzucać przywołanych przez niego argumentów, bowiem stanowią one pewną deklarację. Po pierwsze, że subskrybenci serwisu w większości wolą treści międzynarodowe od lokalnych (choć wątpię, by powiedział to samo o odbiorcach północnoamerykańskich); po drugie, że atrakcyjność najlepszych programów może mieć charakter transkulturowy. Mając dostęp do czarnej skrzynki Netfliksa, jego dyrektor programowy być może wie, że tak właśnie jest, ale warto podkreślić, jak kontrowersyjne pozostają te tezy w kontekście debat o globalizacji mediów.

Czy przeciwstawne stanowiska da się pogodzić? W pewnym sensie problem jest nie do rozstrzygnięcia, ponieważ faktyczna aktywność widzów rzadko podąża za teoriami kulturoznawczymi. Ale jeśli jeszcze raz sięgniemy do historii debaty wokół globalnych przepływów na rynku telewizyjnym, ujrzymy ścieżkę we mgle. Powinniśmy jednak zamienić sposób myślenia „albo-albo” na „zarównojak i”. Widzowie nie wybierają między lokalnym a globalnym, lecz w swej codziennej praktyce łączą jedno i drugie; poruszają się w przestrzeni pomiędzy tymi kwantyfikatorami w różnym czasie i w różnych celach. Mają świadomość, że lokalne programy dobrze odpowiadają ich niektórym potrzebom (wiadomości, sport, programy komediowe oraz typu reality show), ale do realizacji innych czasem lepiej nadają się treści importowane z Ameryki (filmy wysokobudżetowe, widowiska filmowe, thrillery). Oczywiście - sama przewaga ilościowa określonego rodzaju treści w katalogu SVOD nie warunkuje doświadczeń widza w takim stopniu, w jakim dzieje się to w przypadku linearnej ramówki, właśnie dlatego, że zewnętrzną postać katalogu można kształtować i prezentować użytkownikom tak, by trafiać do tych, którzy już wykazali zainteresowanie niszowymi treściami, na przykład skandynawskimi kryminałami, indyjskimi blockbusterami czy filmami z nigeryjskiego Nollywood (wszystkie wymienione kategorie można dziś znaleźć w katalogach Netfliksa).

Z punktu widzenia badań nad telewizją prowadzonych w perspektywie międzynarodowej specyfika Netfliksa nie polega więc na tym, że jego działalność powoduje problemy związane $\mathrm{z}$ transgranicznym przepływem treści - bo z tym mieliśmy do czynienia już wcześniej - lecz na tym, że ten serwis łączy z łatwością elementy lokalne z globalnymi w obrębie jednej platformy i dzięki magicznej mocy filtrowania algorytmicznego funkcjonuje $\mathrm{w}$ postaci wielu różnych 
produktów jednocześnie. Dlatego choć ekonomiczno-polityczny aspekt jego działalności wydaje się ekstremalnym przypadkiem dialektyki lokalne - globalne, która jest fundamentem wielu teorii globalizacji mediów (północnoamerykańskie przedsiębiorstwo zdobywające przewagę nad krajowymi firmami), wewnętrzna struktura serwisu rozmywa granice między lokalnością a globalnością w niespotykany dotąd sposób. To może nie wystarczyć, by przywrócić Netfliksowi niewinność w oczach organów regulacyjnych, które prawdopodobnie nadal będą się koncentrować na liczbie lokalnych tytułów w jego zagranicznych katalogach, ale powinno zachęcić badaczy telewizji do wypracowania nowych konceptualizacji związków między katalogami, algorytmami rekomendacji i krajowymi rozwiązaniami w zakresie polityki medialnej, jako że nasze środowisko medialne w coraz większym stopniu staje się środowiskiem usług na żądanie.

\author{
RAMON LOBATO \\ TłUM. ZOFIA ZIEMANN
}

${ }^{1}$ Napis zamieszczony w dzienniku „Le Monde” z 13.09.2014, czyli tuż przed wejściem Netfliksa na rynek francuski.

${ }^{2}$ Netflix. 2014, Transcript of NFLX Q3 2014 Netflix Inc Earnings Call, ir.netflix.com/results.cfm, por. A. Block, Netflix's Ted Sarandos Explains Original Content Strategy, „Hollywood Reporter", 7.04.2012, www.hollywoodreporter.com/news/netflix-tedsarandos-original-content-309275 (dostęp: 15.12.2020).

${ }^{3}$ Netflix, Top Investor Questions, ir.netflix.com/top-investor-questions (dostęp: 9.01.2020).

${ }^{4}$ Ang. over-the-top service, czyli platforma, której operator odpowiada nie za same treści, lecz tylko za ich dystrybucję za pośrednictwem Internetu, w dodatku nie angażując bezpośrednio dostawcy usług internetowych (przyp. tłum.).

${ }^{5}$ P. H. Miller, R. Rudniski, Market Impact and Indicators of Over the Top Television in Canada: 2012, raport dla Canadian Radio-Television and Telecommunications Commission, www.crtc.gc.ca/eng/publications/reports/rp120 330.htm (dostęp: 15.12.2020).

${ }^{6}$ A. Scarlata, Australian Streaming Services and the Relationship between Viewing Data and Local Television Drama Production, referat wygłoszony na konferencji Australia Screen Production Education and Research Association, Flinders University, Adelaide, Australia, 2015.

${ }^{7}$ G. Fontaine, C. Grece, Origin of Films and TV Content in VOD Catalogues in the EU and Visibility of Films on VOD Services, European Audiovisual Observatory, Strasbourg 2016.
${ }^{8}$ Choć lokalne programy telewizyjne figurują w ofercie Netfliksa częściej niż filmy - około połowy seriali TV w każdym katalogu jest produkcji amerykańskiej, a około jednej trzeciej pochodzi z Europy (głównie z Wielkiej Brytanii, Francji i Niemiec) - seriale z mniejszych krajów europejskich pozostają zasadniczo nieobecne (G. Fontaine, C. Grece, dz. cyt.). Wciąż pojawiają się nowe badania na ten temat, na przykład analiza australijskiego katalogu Netfliksa przeprowadzona w 2017 r. wykazała około dwuprocentowy udział lokalnych treści (R. Lobato, A. Scarlata, Australian content in SVOD catalogs: availability and discoverability. Submission to the Australian and Children's Screen Content Review, apo.org.au/node/134926; dostęp: 15.12.2020). Ze względu na dynamiczny charakter katalogów badania te trzeba traktować jako część ewoluującego przedsięwzięcia naukowego. Istnieje wciąż wiele niewiadomych, jeżeli chodzi o zmienność katalogów w czasie. Niemniej ogólny wniosek o braku lokalnych treści w większości krajowych ofert programowych Netfliksa jest raczej zasadny.

${ }^{9}$ T. Flew, Understanding Global Media, Palgrave, New York 2007, s. 121. Autor przywołuje tu pojęcie ,utrzymywania granic komunikacyjnych" (communicative boundary maintenance), wprowadzone przez Philipa Schlesingera.

${ }^{10} \mathrm{H}$. Schiller, Mass Communications and American Empire, Westview Press, Boulder 1969; A. Mattelart, Multinational Corporations and the Control of Culture: The Ideological Apparatuses of Imperialism, Harvester Press, Brighton 1979; A. Wells, Picture-Tube Imperialism? The Impact of U.S. Television on Latin 
America, Orbis Books, Maryknoll 1972; J. Tunstall, The Media Are American: AngloAmerican Media in the World, Constable, London 1977.

${ }^{11}$ K. Nordenstreng, T. Varis, Television Traffic A One-Way Street? A Survey and Analysis of the International Flow of Television Programme Material, UNESCO Reports and Papers on Mass Communication, Paris 1974. Badacze rozesłali nadawcom telewizyjnym z całego świata kwestionariusz z pytaniami o ofertę programową, uzupełniając uzyskane odpowiedzi własną analizą dostępnych publicznie ramówek.

${ }^{12}$ P. Larsen, Import/Export: International Flow of Television Fiction, UNESCO, Paris 1980; H. Mowlana, International Flow of Information: A Global Report and Analysis, UNESCO, Paris 1985.

${ }^{13}$ E. Katz, G. Wedell, Broadcasting in the Third World: Promise and Performance, Harvard UP, Cambridge 1977, s. 166.

${ }^{14}$ Tamże, s. 7.

15 T. Miller i in., Global Hollywood 2, British Film Institute, London 2005.

${ }^{16}$ J. Chalaby, Transnational Television in Europe: Reconfiguring Global Communications Networks, I. B. Tauris, London 2009, s. 231.

${ }^{17} \mathrm{~J}$. Tomlinson, Cultural Imperialism: A Critical Introduction, Pinter, London 1991; D. Miller, The Young and the Restless in Trinidad: A Case of the Local and the Global in Mass Consumption, w: Consuming Technologies: Media and Information in Domestic Spaces, red. R. Silverstone, E, Hirsch, Pinter, London 1992, s. 163-182.

${ }^{18}$ C. Barker, Global Television: An Introduction, Blackwell, Malden 1997, s. 182.

19 J. Straubhaar, Beyond Media Imperialism: Asymmetrical Interdependence and Cultural Proximity, ,Critical Studies in Mass Communication" 1991, nr 8 (1), s. 39-59.

${ }^{20}$ New Patterns in Global Television: Peripheral Vision, red. J. Sinclair, L. Jacka, S. Cunningham, Oxford University Press, New York 1995.

${ }^{21}$ M. Tracey, The Poisoned Chalice? International Television and the Idea of Dominance, „Daedalus” 1985, nr 114, s. 22.

${ }^{22}$ J. Tunstall, dz. cyt.

${ }^{23}$ M. Buonanno, The Age of Television: Experiences and Theories, Intellect, Bristol 2007, s. 94.

24 Tamże, s. 87.

${ }^{25}$ Global Media and National Policies, red. T. Flew, P. Iosifidis, J. Steemers, Palgrave Macmillan, Basingstoke 2016.

${ }^{26}$ Dyrektywa Parlamentu Europejskiego i Rady 2010/13/UE z dnia 10 marca 2010 r. w sprawie koordynacji niektórych przepisów ustawowych, wykonawczych i administracyjnych państw członkowskich dotyczących świadczenia audiowizualnych usług medialnych, https://eur-lex.europa.eu/legal-content/PL/TXT/HTML/?uri=CELEX:32010L00 13\&from=pl (dostęp: 15.12.2020).

${ }^{27}$ Dyrektywę zmieniono 14 listopada 2018. Zob. h t t p s:// eur-1ex. europa.eu/legalcontent/PL/TXT/HTML/?uri=CELEX:32018L 1808\&from=EN (dostęp: 15.12.2020).

${ }^{28}$ Artykuł 13. postuluje, żeby za sprawą usług medialnych na żądanie promowane byly (...) produkcja utworów europejskich oraz dostęp do nich. Taka promocja mogłaby polegać między innymi na (...) udostepnianiu lub eksponowaniu utworów europejskich w katalogu audycji oferowanych $w$ ramach audiowizualnej ustugi medialnej na żądanie (tamże).

${ }^{29}$ Godne uwagi ze względu na swoją złożoność jest rozwiązanie prawne wypracowane we francuskojęzycznej części Belgii, które uwzględnia wiele czynników, w tym obecność ,specjalistycznych" i ,tematycznych” kolekcji w katalogu, jak również warunki licencji treści europejskich (okres utrzymywania ich w ofercie programowej).

${ }^{30}$ Przegląd aktualnego prawodawstwa w tym zakresie można zaleźć w opracowanym przez Komisję Europejską dokumencie Promotion of European Works in Practice, ec.europa.eu/newsroom/dae/document.cfm?doc_id $=6$ 296 (dostęp: 15.12.2020).

${ }^{31}$ M. Blaney, Netflix ,,Open” to Euro Investment, „Screen International”, 22.11.2014, www.screendaily.com/news/netflix-open-to-euro-investment/5063919.article (dostęp: 15.12.2020); C. O'Brien, Netflix Struggles to Win Over Skeptics in Film-Loving France, „Los Angeles Times”, 28.09.2014, www.latimes.com/business/la-fi-ctnetflix-france-20140928-story.html (dostęp: 12.12.2020); E. Keslassy, Netflix's French Resistance: The Market Reportedly Ripe for the Streaming Service's Next Invasion Boasts Huge Barriers to Entry, ,Variety”, 26.11.2013, s. 28.

${ }^{32}$ Promotion of European Works in Practice, $\mathrm{dz}$. cyt.

${ }^{33}$ Gouvernement de la République française, Consultation sur la directive 2010/13/UE relative aux services de médias audiovisuels (directive $S M A)$. Un cadre pour les médias au 2le siècle. Réponse de la France, ec.euro$\mathrm{pa} . \mathrm{eu} / \mathrm{newsroom} /$ dae/document.cfm?action=di splay\&doc_id=11850 (dostęp: 15.12.2020).

${ }^{34}$ Netflix, Consultation on Directive 2010/13/EU on audiovisual media services (AVMSD). A media framework for the 21st century, s. 16- 


\section{OFERTA PROGRAMOWA...}

-17, http://ec.europa.eu/newsroom/dae/document.cfm?action=display\&doc_id=11459 (dostęp: 15.12.2020).

35 Por. ec.europa.eu/digital-single-market/en/revision-audiovisual-media-services-directiveavmsd (dostęp: 15.12.2020).

${ }^{36}$ Netflix, Consultation... dz. cyt., s. 17.

${ }^{37}$ Przepisy Broadcasting Regulatory Policy 2014 - 444 zobowiązują serwisy VOD do przestrzegania następujących wymogów ilościowych: przynajmniej 5 proc. oferowanych filmów anglojęzycznych, przynajmniej 8 proc. francuskojęzycznych i przynajmniej 20 proc. wszystkich pozostałych programów musi być produkcji kanadyjskiej. Kategoria VOD nie obejmuje usług typu OTT, takich jak Netflix.

${ }^{38}$ S. Robertson, Netflix Leads Streaming Services in Canada, ,The Globe and Mail”, 20.10.2017, www.theglobeandmail.com/report-onbusiness/industry-news/marketing/netflixleads-streaming-services-in-canada/article36678928/ (dostęp: 9.01.2020).

39 J. Anderson, An Over-the-Top Exemption: It's Time to Fairly Tax and Regulate the New Internet Media Services, Canadian Centre for Policy Alternatives, Ottawa 2016, s. 9-10.

${ }^{40}$ Tamże.

${ }^{41}$ K. Taylor, Melanie Joly's Fight for Canadian Culture Is Neither Easy nor Popular, „The Globe and Mail", 16.12.2016, www.theglobeandmail.com/arts/art-and-architecture/melaniejolys-fight-for-canadian-culture-is-neithereasy-nor-popular/article33345113/ (dostęp: 15.12.2020).

${ }^{42}$ S. Globerman, Canadian Content Is Dead; Long Live Canadian Content! Fraser Institute, Calgary 2014.
${ }^{43}$ T. Pedwell, CRTC to Netflix: Since You Won't Co-operate, We'll Ignore You, „CBCNews” 29.09.2013, www.cbc.ca/news/business/crtcto-netflix-since-you-won-t-co-operate-we-llignore-you-1.2781748 (dostęp: 15.12.2020), J. Anderson, dz. cyt, s. 36; I. Wagman, Talking to Netflix with a Canadian Accent: On Digital Platforms and National Media Policies, w: Reconceptualising Film Policies, red. N. Mingant, C. Tirtaine, Routledge, London 2017, s. 209-221. Również koncern Google odmówił udostępnienia komisji tych komercyjnie.wrażliwych danych.

${ }^{44}$ Netflix, What Netflix's Half a Billion CAD Investment in Canada Is Really About, 10.10.2017, https://media.netflix.com/en/company-blog/what-netflixs-half-a-billion-cadinvestment-in-canada-is-really-about (dostęp: 15.12.2020).

${ }^{45} \mathrm{~K}$. Taylor, Mélanie Joly's Netflix Deal Fails to Address the Real Issues for Canadian Content Creators, „The Globe and Mail”, 28.09.2017, www.theglobeandmail.com/opinion/melaniejolys-netflix-deal-fails-to-address-the-realissues-for-canadian-content-creators/article36428560/ (dostęp: 15.12.2020).

${ }^{46}$ Cyt. za K. Nordenstreng, T. Varis, dz. cyt., s. 47.

${ }^{47}$ Netflix, Transcript of NFLX Q1 2015 Netflix Inc Earnings Call, ir.netflix.com/results.cfm (dostęp: 15.12.2019).

${ }^{48}$ Netflix, Transcript of NFLX Q3 2014 Netflix Inc Earnings Call, ir.netflix.com/results.cfm (dostęp: 15.12.2019). 